\title{
Parabolic Life: Toward an Ethics of God's Apocalypse
}

\author{
Philip G. Ziegler \\ University of Aberdeen, UK
}

\begin{abstract}
Christian ethicist Nancy Duff has suggested that an apocalyptic hearing of the gospel elicits a parabolic understanding of the Christian moral life. How might the theological basis and rationale of this claim be elaborated? What is it about human life funded by the gospel of God's apocalypse in Jesus Christ that makes 'parable' an apt description of the quality of its action? And how might these notions be elaborated to enrich our understanding of responsible moral action more generally? This article explores these questions by way of a running conversation with the work of J. Louis Martyn, Christopher Morse and Paul Ricoeur. It concludes by showing the salience of these themes in relation to Bonhoeffer's later reflections upon the distinctive quality of Christian life in the wreckage of Christendom. Overall, the solid currency of a parabolic construal of the character of Christian moral action for the present pursuit of theological ethics is recommended.
\end{abstract}

\section{Keywords}

eschatology, apocalyptic, apostle Paul, parable, Christian life, ethics

For Nancy J. Duff on the occasion of her retirement

'There is no other, real and really ethical disturbance other than that of grace.' $0 \mathrm{~F}^{1}$

1. 'Eine andere, eine wirkliche und wirklich ethische Beunruhigung des Menschen außer der durch Gnade gibt es nicht. . '-Karl Barth, Der Römerbrief 1922 (Zürich: TVZ Verlag, 1940), p. 454, my translation; cf. Karl Barth, The Epistle to the Romans, trans. Edwyn C. Hoskyns (London: Oxford University Press, 1933), p. 430.

\section{Corresponding author:}

Philip G. Ziegler, University of Aberdeen, King's College, Aberdeen, AB24 3UB, UK.

Email: p.ziegler@abdn.ac.uk 


\section{Introduction: Apocalypse and Parable}

This article ventures to reflect upon the specific direction in which a theological ethics self-consciously set in the register of Paul's apocalyptic gospel might run. This striking interpretation of Paul is concerned to do justice to the comprehensive significance of the apostle's 'christologically focused apocalyptic eschatology' for our hearing of the Gospel of God. $1 \mathrm{~F}^{2}$ As Beverly Gaventa concisely sets out:

Paul's apocalyptic theology has to do with the conviction that in the death and resurrection of Jesus Christ, God has invaded the world as it is, thereby revealing the world's utter distortion and foolishness, reclaiming the world, and inaugurating a battle that will doubtless culminate in the triumph of God over all God's enemies (including the captors Sin and Death). This means that the Gospel is first, last, and always about God's powerful and gracious initiative. $2 \mathrm{~F}^{3}$

In some recent work of my own, I have attempted to think through some of the dogmatic implications of hearing Paul's apostolic testimony in this way, including puzzling over what kind of accounts of human agency and of the Christian life might comport with it. $3 \mathrm{~F}^{4}$ Here I want to focus on one specific suggestion in this area, namely, the idea that such a re-hearing of the gospel invites - even requires - us to regard Christian moral action as fundamentally parabolic in nature.

The theological claim that we ought to conceive of ethical action parabolically is perhaps first made programmatic in the work of the theologian and ethicist Paul L. Lehmann, a friend of the young Bonhoeffer and latterly a close colleague of J. Louis Martyn at Union Theological Seminary. Central to the argument of his book, Ethics in a Christian Context, is the claim that:

The Christian character of behavior is defined not by the principal parts of an act but by the functional significance of action in the context of the divine economy and of the actuality of the new humanity. Thus behavior, as Christianity understands it, is not qualitatively but symbolically significant. Or, to put the point in the light of Jesus' characteristic mode of teaching, behavior is ethically defined not by perfections but by parabolic power. $4 \mathrm{~F}^{5}$

Lehmann's proposal was first marshalled as an explicit implicate of a specifically apocalyptic reading of Paul by Nancy J. Duff in her 1989 essay, 'The Significance of Pauline Apocalyptic for Theological Ethics'.5 $\mathrm{F}^{6}$ Duff's essay takes important impetus from the

2. The phrase is from Martinus C. de Boer, Paul: Theologian of God's Apocalypse. Essays on Paul and Apocalyptic (Eugene, OR: Cascade Books, 2020), p. 9.

3. Beverly Roberts Gaventa, Our Mother Saint Paul (Louisville, KY: Westminster/John Knox, 2007), p. 81. For good, recent summary discussion, see James P. Davies, The Cascade Companion to the Apocalyptic Paul (Eugene, OR: Cascade, 2021).

4. Philip G. Ziegler, Militant Grace: The Apocalyptic Turn and the Future of Christian Theology (Grand Rapids, MI: Baker Academic, 2018).

5. Paul L. Lehmann, Ethics in a Christian Context (New York: Harper \& Row, 1963), p. 122.

6. Nancy J. Duff, 'The Significance of Pauline Apocalyptic for Theological Ethics', in Apocalyptic and the New Testament: Essays in Honor of J. Louis Martyn, eds. Joel Marcus and Marion L. Soards (Sheffield: JSOT Press, 1989), pp. 279-96. Duff would later publish a 
pioneering scholarship of J. Louis Martyn in reading Paul as the apostle of a 'gospel of God's apocalypse'. $6 \mathrm{~F}^{7}$ Her central claim is that, as she says, 'apocalyptic themes in Paul challenge descriptions of responsible Christian action as autonomous choices between alternatives' and instead invite us to 'describe responsible action as anticipatory reflections of the New Age inaugurated and promised in Jesus Christ' $7 \mathrm{~F}^{8}$

The upshot of her examination of several of these apocalyptic themes - salvation as redemption, Christ's contestation of antithetical lordships, the advent of the new creation, the turning of the ages, and the lively expectation of the parousia - is to suggest that Christian ethics here is not so much a matter of knowing the good as it is of acknowledgment in act of the One 'who is the Lord of our existence'. $8 \mathrm{~F}^{9}$ Awakened in faith to our having been seized and secured within the orbit of Christ's lordship, our actions now assume the quality of witness. $9 \mathrm{~F}^{10}$ Whether conceived as obedience to Christ's command, or following after him in the manner of discipleship, or 'imitation' or - in an image from Ruben Alves - the disposition of our bodies and selves in accord with the 'rhythms of the future', Christian moral life is a 'living parable of God's action on behalf of creation', a way of being in the world that represents or symbolizes Christ's regnant claim upon a world possessed.10F 11 The common witness of such lives taken in aggregate constitutes the fulfilment of the 'apocalyptic vocation' of the Christian community in the world. The notion that the Christian life ought best to be understood and pursued as a life of obedience and service to the living Lord Jesus Christ is, of course, a longstanding position in the field of theological ethics most typically ordered to concepts of divine command. To specify the quality of this obedience as parabolic, and to do so explicitly in response to pressures arising from a fresh 'apocalyptic' hearing of the gospel, is Duff's signal contribution here, one that lifts up this motif as a hallmark of any 'ethics of God's apocalypse'.

This suggestive claim invites reflective appreciation and elaboration. What more might be said about the theological basis and rationale of this claim? Just what is it about human life funded by the gospel of God's apocalypse in Jesus Christ that makes 'parable'

full-length study of Lehmann's work, Humanization and the Politics of God: The Koinonia Ethics of Paul Lehmann (Grand Rapids, MI: Eerdmans, 1992). I note that Duff herself recruits the passage we have cited from Lehmann in making her own case at p. 291.

7. Appearing as it did in 1989, Duff's essay predates the publication of the two landmarks of this work, namely J. Louis Martyn, Theological Issues in the Letters of Paul (Edinburgh: T\&T Clark, 1997) and Galatians: A New Translation with Introduction and Commentary (New York: Doubleday, 1997). As the notes make clear, Duff worked directly with only three of the seventeen essays eventually collected in Theological Issues in the Letters of Paul.

8. Duff, 'Significance of Pauline Apocalyptic for Theological Ethics', pp. 281-82.

9. Duff, 'Significance of Pauline Apocalyptic for Theological Ethics', p. 283.

10. The claim that all human action was but 'witness' to the catastrophic action of divine grace was a signal motif of Barth's treatment of ethics in his Epistle to the Romans, where he speaks of the quality of responsible human action as 'Eine Opfer' which is 'vielmehr eine Demonstration'—see Barth, Der Römerbrief 1922, pp. 454-55.

11. Duff, 'Significance of Pauline Apocalyptic for Theological Ethics', pp. 292-93; Duff cites Alves from his Tomorrow's Child: Imagination, Creativity, and the Rebirth of Culture (New York: Harper \& Row, 1972), pp. 195-96. 
so apt a characterization of the quality of its action? And how might the notion of 'parable' and 'parabolic' be elaborated so as to thicken our understanding of Christian moral action further still? In particular, how might these ideas inform our grasp of what it means to characterize such action as 'responsible', as Duff notably does? I hope to advance consideration of these questions, first, by discussion of some of Martyn's later work in which he further developed his account of Paul's understanding of the Christian as moral subject. Next, consideration of the work of Christopher Morse will afford us another instructive example of a similarly 'apocalyptic' view of the parabolic character of theological ethics, which while also indebted to Martyn's New Testament scholarship, complements Duff's earlier focus on Paul with its own concentration on the theme of the kingdom of heaven. Finally, I briefly draw out the salience of these themes in conversation with a late text of Dietrich Bonhoeffer which contemplates the distinctive quality of Christian life in the wreckage of Christendom. These concluding reflections look to recommend the solid currency of a parabolic construal of the character of Christian moral action for the present pursuit of theological ethics.

\section{Eschatologically Indicative Life}

From the time of his earliest work on Paul, Martyn argued energetically that the paraenesis we encounter in Paul's letters presupposes that the sovereign advent of divine grace in Jesus creates new and peculiar conditions of possibility for the everyday life of the Christian community and its members. Standing as Paul does at the end of the tumultuous career of the human agent - from creation and election through disobedience into a captivity to Sin in which it becomes simply 'incompetent' to hear and to heed moral injunction generally and the Law in particular - the apostle can only exhort his first (and subsequent) readers to action because he envisages that 'God changes human agency itself . . . forming this new human agent in the image of the crucified Son . . . by sending the Spirit of the Son into its heart (Gal 4:6; Rom 8:29)'.11F ${ }^{12}$ The everyday life of the church just 'is the scene of God's rectification' where, as Paul sees it, the Spirit 'remains the primary actor'; for this reason, 'far from being decision-oriented ethics directed to the individual human will as such, Paul's exhortations are fundamentally descriptive of the corporate patterns of life that constitute God's continuing apocalyptic rectification'. $12 \mathrm{~F}^{13}$

In his latter years, Martyn continued to reflect upon the way in which Paul's grasp of 'the context of the divine economy and of the actuality of the new humanity' - as Lehmann had put it - positions human agency. He eventually came to characterize this situation as one marked by 'a second, ultimately determinative form of dual agency' — or more precisely, a 'redemptive dual agency with [an] asymmetrical form' - arising from

12. J. Louis Martyn, 'Epilogue: An Essay in Pauline Meta-ethics', in Divine and Human Agency in Paul and His Cultural Environment, eds. John M. G. Barclay and Simon J. Gathercole (London: T\&T Clark, 2007), p. 180; original emphasis (hereafter all emphasis in quotations is original). See also the related development of these themes in fine in the thematic excurses of his Galatians.

13. Martyn, Theological Issues in the Letters of Paul, p. 234. He explicates the exegetical grounds for this summary claim at length in chapters 14 and 15, pp. 235-66. 
the fact that, as he puts it, 'this invasive God consistently participates in human morality itself' $13 \mathrm{~F}$ It is in virtue of the steadfast redeeming activity of the Spirit of the Son that faith and obedience are not invited but rather 'incited by the power of the gospel' $:{ }^{14}$ here, the interval, as it were, between the action of the Spirit of Christ and that of the believer is foreclosed in such a way that it is simply not apt to conceive of 'two steps', namely, a first, divine offer or invitation that is then met and answered by a second, subsequent, and autonomous human act. Rather, as Martyn explains,

love, joy, and living at peace are deeds of human beings, to be sure, but specifically deeds carried out every day as the Spirit of Christ bears its fruit in the dual agency known in the daily life of the church, the 'body of Christ' (1 Cor 11) . . . that is daily brought into being by God's own participation in the moral drama, as he placed that drama under the liberating lordship of Christ. $14 \mathrm{~F}^{15}$

Martyn is struck by how Paul in Galatians 5 details the promise of 'life in the Spirit' ( $5: 16)$ by 'first of all describing for the Galatians the world in which they actually live post Christum'. $15 \mathrm{~F}^{16}$ This privileging of the indicative over the imperative voice comports with the asymmetry of the dual agency Martyn espies here, pointing first and foremost to that which God is doing-bearing fruit by the Spirit - as the immediate inciting source and ground of human doing. We might take this whole account as an exegetical-theological gloss on the apostle's paradigmatic assertion that 'I have been crucified with Christ; and it is no longer I who live, but it is Christ who lives in me. And the life I now live in the flesh I live by faith in the Son of God, who loved me and gave himself for me' (Gal. 2:19b-20). What Martyn offers here, in short compass, is a description of Christian moral agency that comports with Ernst Käsemann's paradigmatic judgment that, for Paul, human existence is fundamentally 'other determined', stemming decisively from outside the self, a judgment notably advanced by the important recent work of Susan Eastman on the essential permeability of the human self to both $\mathrm{Sin}$ and Spirit. $16 \mathrm{~F}^{17}$

I want to suggest that Martyn's later and more elaborate account of the 'dual agency' of Christian action serves to justify further why we ought to construe the moral lives of Christians as essentially parabolic, that is, as the present enactment of forms of life and ways of being in the world that are creaturely parables of the divine and eschatological

14. J. Louis Martyn, 'Afterword: The Human Moral Drama', in Apocalyptic Paul: Cosmos and Anthropos in Romans 5-8, ed. Beverly Roberts Gaventa (Waco, TX: Baylor University Press, 2013), pp. 163, 165; Martyn, 'Epilogue', p. 182.

15. Martyn, 'Afterword', p. 165. Cf. J. Louis Martyn, 'The Gospel Invades Philosophy', in Paul, Philosophy, and the Theopolitical Vision, ed. Douglas Harink (Eugene, OR: Cascade Books, 2010), pp. 20, 31-33. Martyn famously spoke of the chief competitor of Paul's own view as the 'two-step dance' in which a divine precept confronts a morally competent human subject with a possibility, which can and must be accepted or rejected by an autonomous act of will'.

16. Martyn, Theological Issues in the Letters of Paul, p. 258.

17. See Ernst Käsemann, 'On Paul's Anthropology', in Perspectives on Paul, trans. Margaret Kohl (Philadelphia: Fortress, 1971), pp. 26-28; Susan Eastman, Paul and the Person: Reframing Paul's Anthropology (Grand Rapids, MI: Eerdmans, 2017). 
activity of God from which they immediately derive, by which they are justified, and in whose celebration and service they are undertaken. In as much as it is lived 'in Christ' and brought into being by the present activity of the Spirit, such lives correspond in human ways to the reign of God and so attest the contours of that reign in the midst of the 'yet unredeemed world'.17F ${ }^{18}$ They are thus essentially 'testimony', i.e., all-too human ways of being in the world that nevertheless as fruit of the Spirit manage to 'tell forth' about the 'liberating lordship of Christ' and indicate something of the reality of the inaugurated overthrow of the anti-God powers that is afoot with the advent of redemption. Conceiving of moral action as parabolic in this way ensures our ethics never forgets that all human action which 'says', as it were, that 'Christ is Lord' owes itself to the graciously asymmetrical agitation of the Spirit as 'primary actor' $.18 \mathrm{~F}^{19}$

Furthermore, like Jesus' own parables, such Christian lives participate in the paradoxical advent of the eschatological truth of the Kingdom in the midst of the world that is passing away; in their own way they are caught up in the epistemological crisis to which the gospel gives rise. If 'God's liberating invasion is not demonstrable in categories of the Old Age or with the means of perception native to the Old Age', then the saving apocalypse of the gospel demands that we now regard the world - as Martyn long argued - with a 'bi-focal vision' that espies 'both the enslaving Old Age and God's invading and liberating new creation' at one and the same time. $19 \mathrm{~F}^{20}$ Ingredient in the structure of parabolic life is something fundamental to the structure of parables themselves: namely, the paradoxical fact that the 'extraordinary is like the ordinary' only because the extraordinary has come upon the ordinary, is 'at hand', in a way that makes everything strange and new. $20 \mathrm{~F}^{21}$ Thus entangled from their origin to their end with the advent of the reign of God of which they tell, parables have an inconvertible quality: they are not liable to abstract restatement as a law or principle for they 'allow no translation in conceptual language' as hearing them requires that one 'thinks through the metaphor and never beyond' it. $21 \mathrm{~F}^{22}$ For this reason, Ricoeur considered that 'nothing is more foreign to the spirit of the gospel than the pretension of deducing a fixed morality from the paradoxical precepts of Jesus. In return, what we can do is give some signs of this

18. The fifth article of the Barmen Declaration explicitly sets the church's life of witness and service in the political present to the living lordship of Christ against the backdrop of the 'still yet unredeemed world'.

19. We might think of this as an expansive moral theological gloss on 1 Cor. 12:3: 'Therefore I want you to understand that no one speaking by the Spirit of God ever says "Let Jesus be cursed!" and no one can say "Jesus is Lord" except by the Holy Spirit'.

20. Martyn, Theological Issues in the Letters of Paul, p. 284. Nancy Duff cites a variant of this claim in which Martyn speaks of seeing at one and the same time, 'the profound depths of evil and the profound heights of God's redeeming power'; see Nancy J. Duff, 'The Strange Worlds of Apocalyptic, Christian Ethics, and Princeton Theological Seminary', Union Seminary Quarterly Review 65.1-2 (2014-15), p. 115.

21. Paul Ricoeur, 'Listening to the Parables of Jesus', in The Philosophy of Paul Ricoeur: An Anthology of His Work, eds. Charles E. Reagan and David Stewart (Boston, MA: Beacon Press, 1978), p. 239.

22. Ricoeur, 'Listening to the Parables of Jesus', p. 242. 
new economy'. $22 \mathrm{~F}^{23}$ Could it be that since parables, as Ricoeur also once remarked, are 'the culminating genre in the whole biblical literature', so parabolic action is correspondingly the 'culminating genre' of a Christian life, understood apocalyptically? $23 \mathrm{~F}^{24}$

Taking stock of the legacy of Martyn's work recently, Duff has rightly reaffirmed that on this telling, the work of theological ethics simply cannot be 'to turn what God has done into universal principles' but rather can only be 'to become living parables of the New Creation with our actions always pointing to what God has done for us and for the world' $24 \mathrm{~F}^{25}$ The intuition I am chasing here is that this is so because the ideas of 'bifocal vision' and 'dual agency' conspire together to fund a parabolic construal of moral action. Both categories concern the way in which the new is conceived in relation to the old but not within the frame of the old: 'dual agency' denotes how a Christian life is overrun by the invasion of divine grace and set free to perform, even now, the longed-for fruitful liberty of the children of God; 'bi-focal vision' points up the quality of perception involved in discerning the reality and significance of such performances, a catching sight of God's redeeming power at work in lives that are no less human for that. So, as with the parables of Jesus themselves in which the all-too-human, secular, and everyday become the site of surprising and disruptive attestation of the ever-new truth of the gospel of God, so too might we conceive of Christian moral action as the inspired performance of a kind of 'prudent unlawfulness' amidst the creaking schemes of the present age, a parabolic attestation of the new creation in, with, and under-but also no doubt subversively contra-the old $25 \mathrm{~F}^{26}$

It is precisely this reality of the eschatologically 'new' already breaking into and breaking up the 'old' of which the parables of Jesus speak that makes Christian moral existence uneasy and often at odds with 'how things work around here'. It is a way of being human that is openly set in the service of a 'kingdom not of this world' amidst the manifold normative regimes of the 'kingdoms of this world'. The Christian life is parabolic - and disturbingly so-because it is proleptic. $26 \mathrm{~F}^{27}$ The fundamental importance of this disruptive eschatological element was something Christopher Morse first discussed in relation to Moltmann's work, finding instruction there in the way that our

23. Paul Ricoeur, 'The Logic of Jesus, the Logic of God', in Figuring the Sacred: Religion, Narrative, and Imagination, trans. David Pellauer, ed. Mark I. Wallace (Minneapolis: Fortress Press, 1995), p. 283. For wider discussion of this piece, see David Ford, 'Paul Ricoeur: A Biblical Philosopher on Jesus', in Jesus and Philosophy: New Essays, ed. Paul K. Moser (Cambridge: Cambridge University Press, 2012), pp. 169-93.

24. Cited in James Fodor, Christian Hermeneutics: Paul Ricoeur and the Refiguring of Theology (Oxford: Clarendon Press, 1995), p. 236.

25. Duff, 'Strange Worlds', p. 115.

26. Kornelis H. Miskotte, The Roads of Prayer, trans. John W. Doberstein (New York: Sheed and Ward, 1968), p. 160, speaks of the practice of praying the Lord's Prayer as a 'resistant' and 'belligerent' act of 'prudent unlawfulness' necessarily subversive of the powers that be.

27. As Lehmann writes, 'The fact of the new humanity, established in and by the second Adam, means that all behavior is a fragmentary foretaste of the fulfilment which is already on its way'; or again: "The Christian lives neither by his "Adamic" past nor by his "Christian" past, but by the future, of which his present is an exhilarating foretaste'. Lehmann, Ethics in a Christian Context, pp. 122, 123. 
declarations and enactments of eschatological promise 'anticipate, initiate, and present the future' in ways that inevitably 'contradict the present'. $27 \mathrm{~F}^{28}$

A clutch of interrelated works that bookend Morse's career revisit and extend this theme in order to ask what might follow if the modern 'post-Kantian reversal' of the significance of New Testament apocalyptic for theology and ethics were itself reversed. $28 \mathrm{~F}^{29}$ In this, he supplements the Pauline concentration with specific interest in the motif of the kingdom of God. As he explains, it is the 'at-handedness' of the kingdom that is 'basic to the gospel's apocalyptic testimony' pointing as it does to the advent of a 'new state of affairs coming to pass in contravention of an opposing schema of this world' - something proximate though never approximated in the present situation —and which represents 'the most inescapable reality now facing us' $29 \mathrm{~F}^{30}$ To live from the effective reality of the heavenly kingdom-at-hand is, Morse argues, to wager in hope that 'what embraces every creaturely struggle for life is a virtus, a power of heaven claiming our participation, beyond even our consciousness and death, as no power on earth can' $.30 \mathrm{~F}^{31}$ Here, the decisive concern of any Christian ethic must be exploration of 'the relation of heavenly doing, or the virtus of a heavenly politeia, with our doing on earth, as participation in accord with this politeia and basileia at hand' or, said otherwise, of discerning the moral significance of 'a disposing by God's forthcoming that is not up to us and our volition' $.31 \mathrm{~F}^{32}$

It is this leading emphasis on the decisive eschatological fact and defining eschatological form of 'God's doing in the situation' that leads Morse toward a construal of Christian action as parabolic in nature. Just as Jesus' own person and paraenesis is inseparable from his parabolic teaching of the kingdom which is at hand, so too is Christian life inextricably located and enacted 'under heaven' in this eschatological sense. As Morse argues, to pray that God's will be enacted by us on earth 'as it is in heaven' invites and demands seeking just what 'heavenly doing' is afoot in the world in virtue of the pressing advent of the kingdom so as to discern the location and direction of the "contravening interruption of the status quo taking form and taking place in reality now at hand' $.32 \mathrm{~F}^{33}$ Though we cannot here rehearse Morse's extensive and insightful elaboration of this theme in the exposition of the theology of Dietrich Bonhoeffer he offers, we can observe that — as with Duff — he finds in Bonhoeffer's own republication of an ethics

28. Christopher Morse, The Logic of Promise in Moltmann's Theology (Philadelphia, PA: Fortress Press, 1979), p. 41.

29. Christopher Morse, "If Johannes Weiss is Right. . ." A Brief Retrospective on Apocalyptic Theology', in Apocalyptic and the Future of Theology: With and Beyond J. Louis Martyn, eds. Joshua B. Davis and Douglas Harink (Eugene, OR: Cascade, 2012), p. 140, as well as The Difference Heaven Makes: Rehearing the Gospel as News (London: T\&T Clark, 2010), especially pp. 82-86 on the theme of the modern 'reversal of direction in envisaging the kingdom'. Some of the arguments of the latter were first trialled in his essay, 'The Virtue of Heaven: From Calvin to Cyber-Talk and Back', Modern Theology 19.3 (2003), pp. 317-28.

30. Morse, “If Johannes Weiss is Right. ..", pp. 144, 149 and Morse, The Difference Heaven Makes, pp. 21, 24.

31. Morse, 'The Virtue of Heaven', p. 326.

32. Morse, The Difference Heaven Makes, p. 76.

33. Morse, The Difference Heaven Makes, p. 97. 
of human response to the living and reality-forming power and agency of the Word of God, a key source and ally. In any case, whenever the eschatological environment is forgotten, Morse suggests, the framework of the Christian life readily degenerates into 'hortatory moralism'. $33 \mathrm{~F}^{34}$

The hope and promise of the Christian moral life is that - in virtue of the lively and formative agency of Word and Spirit - the watching, waiting, seeking, loving, and struggling incited by the kingdom that is at-hand can and will also incite a doing of the will of God on earth 'as in heaven', issuing in forms of life and discrete actions which echo and repeat in properly creaturely ways that 'heavenly doing' from which they arise, and so are translucent to their origin in God's action.34F ${ }^{35}$ The contours of this account track closely with Martyn's talk of dual agency discussed above and they lead Morse explicitly to view Christian life as parabolic. He introduces the notion by invoking Karl Barth, drawing an arc from the Swiss theologian's early assertion in his Römerbrief that 'all human doing or not-doing is simply an occasion or opportunity of pointing to that which alone is worthy of being called "action", namely the action of God', to his late remark that, "we can and must be prepared to encounter "parables of the kingdom" in the full biblical sense, not merely in the witness of the Bible and the various arrangements, works and words of the Christian Church, but also in the secular sphere, i.e., in the strange interruption of the secularism of life in the world' $35 \mathrm{~F}^{36}$ Morse's own argument is precisely that the 'arrangements, works and words' of the Christian life have this kind of force, being earthly human enactments which 'parabolically express what is happening in and breaking forth from heaven' and so attest primarily to the reality-making action of God.36 $\mathrm{F}^{37}$ The pattern of asymmetrical origination and relation, living derivation, and the freed creaturely correspondence which 'tells' of the invasive, unsettling, and inciting kingdom of God without over-identification with it - such are the contours or grammar of the 'parabolic' quality of Christian moral life. Such a life involves a posture of discerning dependence rather than casuistic self-confidence. Pressed upon by heaven in the way Morse describes, such a life ventures specific acts and trials particular forms of life in the free and grateful hope of bespeaking the gospel. The eschatological reality and reserve funding this vision of the Christian life emphasises its provisional and pilgrim character, requiring us to anticipate with joy the prospect of being overtaken and outpaced by other, better, more apt, and eloquent performances of faith to come.

34. Morse, The Difference Heaven Makes, pp. 81, 97.

35. Morse identifies the five gerunds listed here based on imperatives to attend to 'heaven's forthcoming'. The Difference Heaven Makes, pp. 97-98.

36. Karl Barth, The Epistle to the Romans, trans. Edwyn Hoskyns (Oxford: Oxford University Press, 1933), p. 432, cited by Morse, The Difference Heaven Makes, p. 85, and Karl Barth, Church Dogmatics IV/3.1, p. 117, cited by Morse, 'The Virtue of Heaven', p. 323 and "'If Johannes Weiss is Right"', pp. 152-53. Morse always notes the German that underlies the final phrase - 'der Profanität des Weltlebens' — which might, it seems to me, be a conceptual restatement of the 'schema' of the present and passing age, something to which the English does readily point.

37. As expressed by Nancy J. Duff, 'Book Forum on Christopher Morse, The Difference Heaven Makes: Rehearing the Gospel as News', Theology Today 68.1 (2011), p. 77. 
Of course, by attending to the specific ethical import of the apocalyptic proclamation of the kingdom of heaven, Morse also draws thinking about the Christian life into even greater proximity with the specific genre of Jesus' parables themselves. The notion of 'discernment' so central to Morse's theology keeps company with Paul Ricoeur's claims about 'imagination' in his own treatment of the 'logic' of parables. Reflecting on the prominence of excess and hyperbole in such stories, he writes:

Parables, paradoxes, hyperboles, and extreme commandments all disorient only to reorient us. But what is reoriented in us? and in what direction? I would say that what is reoriented by these extreme sayings is less our will than imagination. Our will is our capacity to follow without hesitation that once-chosen way, to obey without resistance the onceknown law. Our imagination is the power to open us to new possibilities, to discover another way of seeing, or acceding to a new rule in receiving the instruction of the exception. $37 \mathrm{~F}^{38}$

The way Ricoeur sets in simple apposition the epistemic idea of 'another way of seeing' and the ethical idea of 'acceding to a new rule in receiving the instruction of the exception' is telling and apt here. Said differently and in a more explicitly theological idiom, we might say the mainspring for action coherent with the apocalypse of the gospel of God is the seizure of the imagination by the disorienting and reorienting reality of the advent of God, the generation of what Stephen Webb once called a 'hyperbolic imagination of God's love' which, 'informed by the (il)logic of the parables and the narrative of Jesus' triumph through suffering, sees the world as it really is, but, in addition, sees it as it most certainly is not' $.38 \mathrm{~F}^{39}$ Such a rectified imagination is perhaps the organ of a parabolic 'ethics of heaven' since, as Morse himself puts it, 'the key issue . . . is what one takes "the real world" to be', that is, just what are the most relevant 'current conditions under which our life is really being lived'. $39 \mathrm{~F}^{40}$

38. Ricoeur, 'The Logic of Jesus, the Logic of God', p. 281. Elsewhere Ricoeur writes, 'hyperbole leads back to the heart of existence. The challenge to the conventional wisdom is at the same time a way of life. We are first disoriented before being reoriented' ('Listening to the Parables of Jesus', p. 244). The centrality of this dialectical pattern of radical disorientation/ re-orientation has been identified as a key feature of Ricoeur's own theological ethics; see John Wall, 'The Economy of the Gift: Paul Ricoeur's Significance for Theological Ethics', Journal of Religious Ethics 29.2 (2001), pp. 239-40.

39. Stephen Webb, 'The Hyperbolic Imagination: Theology and the Rhetoric of Excess', Theology Today 50.1 (1993), p. 64. In this connection, one cannot but think of the close resonance with Martyn's appeal to the 'bi-focal vision' funded by the apocalypse of the gospel of God.

40. Morse, "II Johannes Weiss is Right. ..", p. 149; Morse, The Difference Heaven Makes, p. 24. For a recent proposal concerning the central place of imagination in theological and more broadly Christian existence, see Garrett Green, Imagining Theology: Encounters with God in Scripture, Interpretation, and Aesthetics (Grand Rapids, MI: Baker Academic, 2020), especially the essay 'Toward a Normative Christian Imagination', pp. 1-24. 


\section{Conclusion: Prayer and Righteous Action as Parable}

In May 1944 Bonhoeffer wrote a letter addressed to the infant son of Eberhard and Renate Bethge on the occasion of his baptism. $40 \mathrm{~F}^{41}$ It is apt that Bonhoeffer should take the celebration of a baptism - that act of recognition of a life having been seized by grace, and incorporated into the community of those made responsible for the joyful, worshipful, and free service and witness of the God of the gospel — as an occasion to contemplate the future shape of the church and of Christian life within it. Alongside advice for the baby's father and mother and some speculation about the changing world in which the boy will grow up, Bonhoeffer ventures arresting claims about what it will mean to be a Christian in coming years. He imagines a crisis of 'melting' and 'remoulding' that will drive the church 'all the way back to the beginnings' of its understanding of the faith, and demand a new and unnerving encounter with the radicality of the gospel and its claims that will convict the church of just how remote and elusive it has all become. Co-opted, complicit, and compromised by its entanglements in the events of the Third Reich, Bonhoeffer envisages that:

the words we used before must lose their power, be silenced, and we can be Christians today in only two ways, through prayer and in doing justice among human beings. All Christian thinking, talking, and organizing must be born anew, out of that prayer and action . . . It is not for us to predict the day - but the day will come - when people will once more be called to speak the word of God in such a way that the world will be changed and renewed. It will be in a new language, perhaps quite a nonreligious language, but liberating and redeeming like Jesus's language, so that people will be alarmed and yet overcome by its power- the language of a new righteousness and truth, a language proclaiming that God makes peace with humankind and that God's kingdom is drawing near. $41 \mathrm{~F}^{42}$

It is striking that when Bonhoeffer imagines this future language of witness he conceives of it on the model of Jesus' own parabolic discourse: his alarming, nonreligious, powerful telling-forth of the kingdom of God which is at hand. I would like to suggest pressing further that in light of the arguments canvassed above, we ought also to see the prayerful righteous action Bonhoeffer envisaged to be the church's chastised, interim mode of witness - i.e., the lives of Christians who 'pray and do justice and wait for God's own time' $42 \mathrm{~F}^{43}$ — as essentially parabolic in nature in much the same way.

41. Dietrich Bonhoeffer, 'Thoughts on the Day of the Baptism of D.W.R., May 1944', Dietrich Bonhoeffer Works, English Edition (DBWE) 8 (Minneapolis, MN: Fortress Press, 2005), pp. 383-90.

42. Bonhoeffer, $D B W E$ 8, pp. 389-90. One thinks of the ways in which religious, and even specifically Christian language, was exploited and entangled with the ideological programme of the Nazi regime to produce that 'dignity' and 'radiant fog of religion' key to its propaganda success during much of Bonhoeffer's adult life - the cited phrases are drawn from the classic account by Victor Klemperer, The Language of the Third Reich: Lingua Tertii Imperii-A Philologist's Notebook, trans. Martin Brady (London: Bloomsbury, 2013), pp. 117-18.

43. Bonhoeffer, DBWE 8, p. 390. 
Such action itself accompanied by prayer is the parabolic language, as it were, of the new in the midst of the old, the language which the Spirit of Christ makes available to Christians as the form of their everyday lives, even - and perhaps especially - when the direct discourse of Christian faith and witness is compromised, alienated, or as in Bonhoeffer's own

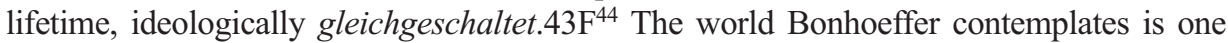
after Christendom. Indeed, as is well known, Bonhoeffer imagined a future in which Christian faith and life would be required to take leave of its long entanglement with the lineaments of human religiosity - namely, of its orientation to the all-too necessary God who stabilized our socio-political and psychological constitutions, and cemented the gaps in our metaphysical, scientific, and heuristic schemes - and to experiment with 'non-religious' forms in a late modern world forced to 'come of age'. He contemplates Christian life lived outwith the received schema of religion, a 'religionless Christianity'. These thoughts have as their deepest mainspring Bonhoeffer's recognition of the formative eschatological reality of divine reconciliation in Christ - for which in his Ethics he coined the term Christuswirkl ichkeit.44F ${ }^{45}$ Indeed, as he noted in a letter of June 1944, 'the issue that concerns me: the claim of Jesus Christ on the world that has come of age'. ${ }^{46}$

I take Bonhoeffer's baptismal remarks to suggest that 'prayer and righteous action' themselves are the tenable currency of a Christian life faithfully committed to testifying to this claim of Christ on the modern world by parabolically enacting the "polemical unity' (as he styled it) of faith and worldly existence - of the kingdom of heaven and the earth - that he understood faith to incite and enjoin and which is the very stuff of ethical life. $45 \mathrm{~F}^{47}$ This is so because righteous action is, for Bonhoeffer, always responsible action, that is, action fundamentally responsive to and ultimately accountable to 'God's reality revealed in Christ in the reality of the world' for its own truth and effectiveness. $46 \mathrm{~F}^{48}$ To recall Duff's formulation, we might say that Christian moral action is responsible first and foremost because it arises from - and so is responsive and accountable to - God's own redemptive action in Jesus Christ, responsible to the reality of the 'new age' which is breaking in, responsible to its crucified Lord. Or in Morse's idiom, such action is responsible in the midst of the earth to what it hears of the forthcoming of heaven. This particular grammar of responsibility funds a parabolic view of Christian action because it indexes such action to the inciting reality of God's sovereign redemption in Jesus Christ. As Martyn summarizes the matter in relation to Paul's ethical vision: 'the standard is the real world that has now been made what it is by the event of God's gracious invasion via his Son and the Spirit of the Son'. ${ }^{49}$ Even if we still await that 'new

44. Gleichschaltung was the term of art for the ideological alignment of all aspects of state, culture, and church with the ends and means of the National Socialist Party.

45. Dietrich Bonhoeffer, Ethics, DBWE 6, pp. 58-59. For discussion of this claim see my essay, 'Secularity and Eschatology in Bonhoeffer's Late Work', in Dietrich Bonhoeffers Theologie heute: Ein Weg zwischen Fundamentalismus und Säkularismus?, eds. J. De Gruchy, S. Plant and C. Tietz (Gütersloh: Gütersloher Verlaghaus, 2009), pp. 124-38.

46. Bonhoeffer, DBWE 8, p. 451.

47. Bonhoeffer, $D B W E$ 6, pp. 59-60.

48. Bonhoeffer, $D B W E$ 6, p. 58.

49. Martyn, Galatians, p. 567. 
language' of proclamation of which Bonhoeffer dreamed, the parabolic eloquence of prayerful righteous action undertaken by those who profess 'a primordial adhesion to the life, the words, the death of Jesus' may yet say something true about the 'real world' of which Martyn writes. $47 \mathrm{~F}^{50}$ Indeed, an apocalyptic theological ethics envisages that what Bonhoeffer says of that 'new language' is also and already a fitting description of the parabolic language in which Christian moral action can and should speak: 'perhaps a nonreligious language, but liberating and redeeming like Jesus's language, so that people will be alarmed and yet overcome by its power-the language of a new righteousness and truth, a language proclaiming that God makes peace with humankind and that God's kingdom is drawing near'. 51

Finally, Bonhoeffer's explicit coupling of prayer and parabolic action is notable in the context of our reflections here. In fact, we might consider these to be mutually qualifying descriptions of the one life-act of Christians. On the one hand, because of its eschatological dimension all parabolic actions have the quality of prayer, being actions by which we invite the heavenly kingdom to 'come down' so that the interval between the provisional parable and ultimate reality might be visibly overtaken, actions by which we plead, 'let it be so!'. On the other hand, the invocation of God in prayer is itself a parabolic action in as much as its very form attests to the truth that we live from the new in the midst of the old, that we do not possess or dispose over that from which we live, but must rather attend upon its coming, receive it, and so petition for it, invoking God's own living action as the necessary and necessarily asymmetrical basis of our lives. With its invocation of God-veni Creator Spiritus! - the act of prayer in particular 'tells' of the rectifying action of God from which it — and all true Christian action — springs. In a sense all invocation of God in prayer reduces to prayer for the manifest coming of the kingdom of God. In this way it parabolically embodies and 'tells' of our utter reliance upon the militant grace of the God of the gospel if we are to act aright, that is, if we are truly to act in the public service of the One whose coming is bringing the 'present evil age' under the sway of his 'new creation'. $48 \mathrm{~F}^{52}$

\section{ORCID iD}

Philip G. Ziegler (iD) https://orcid.org/0000-0003-3555-4102

50. Paul Ricoeur, Living Up to Death, trans. David Pellauer (Chicago: University of Chicago Press, 2009), p. 69, offers this as a definition of faith.

51. Bonhoeffer, DBWE 8, p. 390.

52. The primary place of prayer in Christian ethics is an important aspect of Barth's moral theology; see Karl Barth, The Holy Spirit and the Christian Life: The Theological Basis of Ethics, trans. Robin W. Lovin (Louisville, KY: Westminster/John Knox, 1993), pp. 67-68 and again, The Christian Life (London: T\&T Clark, 2017). For discussion see Eberhard Jüngel, 'Invocation of God as the Ethical Ground of Christian Action: Introductory Remarks on the Posthumous Fragments of Karl Barth's Ethics of Reconciliation', in Theological Essays I, trans. John Webster (Edinburgh: T\&T Clark, 1989), pp. 154-72 and most recently Ashley Cocksworth, Karl Barth on Prayer (London: T\&T Clark, 2015). 